\title{
CLONING AND EXPRESSION OF A MURE LIGASE ENZYME AS A POTENTIAL TARGET AGAINST BACTERIA XANTHOMONAS ORYZAE PV. ORYZAE
}

\author{
THI-HUYEN TRAN ${ }^{1}$, NGOC-TUAN NGUYEN ${ }^{1}$, LIN-WOO KANG ${ }^{2}$ \\ ${ }^{1}$ Institute of Biotechnology and Foodtechnology, Industrial University of Ho Chi Minh \\ ${ }^{2}$ Department of Biological Sciences, Konkuk University, Korea \\ tranthihuyen@iuh.edu.vn
}

\begin{abstract}
Xanthomonas oryzae pv. oryzae (Xoo) is causal agent of bacterial blight (BB) in rice. Many genes in Xoo have been identified in recently years. One of these genes, a gene coded for uridine diphosphate (UDP)-MurNAc-tripeptide ligase (MurE), catalyses the addition of meso-diaminopimelic acid (m-DAP) into peptidoglycan by coupled to the hydrolysis of ATP has more popular interest. However, there are no experimental data to confirm hypothesis of this enzyme in Xoo. A significant overview at the ATP binding site of most the MurE ligases demonstrated much more variable with amino acid sequence identities in this part, variable percentage around 22 to $26 \%$. Besides, a refined homology structural feature between EcMurE and XooMurE will very important for determining possible involvement of the MurE ligase activity in Xoo. Therefore, a new recombinant protein named XooMurE from Xoo was purified with the N-terminal His-tagged form through a Ni-NTA column in this study. After purification, the Histag was removed then out of the N-terminal His-tagged XooMurE by TEV protease. Purification effectiveness of XooMurE over $95 \%$ in this study could produce an essential material for e studies about mechanism of XooMurE and consequently available direction for discovering novel anti-bacterial compounds against Xanthomonas oryzae pv. oryzae (xoo).
\end{abstract}

Keywords. Escherichia coli (E. coli), His-tag, pET11a plasmid, purity effectiveness

\section{INTRODUCTION}

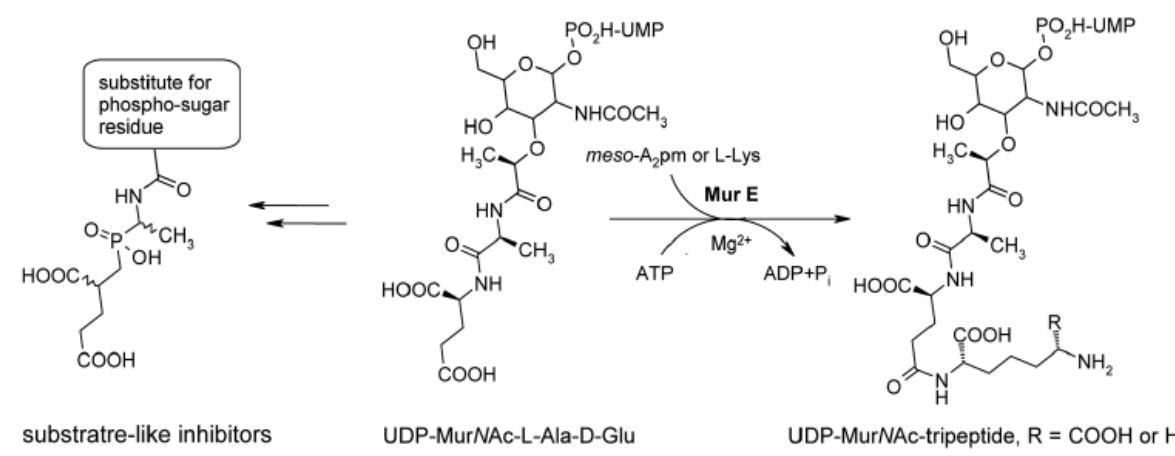

Figure 1.1 Schematic pathway of MurE ligase are involved in de novo synthesis of the bacterial cell wall peptidoglycan [9].

Rice is the most cultivated food crop, feeding more than half of the world population [1]. Although a rapidly growing global population has led to an increase in demand for rice, severe environment stresses, such as climate change and disease pressures, add challenges to rice production [2]. Xanthomonas oryzae pv. oryzae (Xoo) causes bacterial blight, which is one of the most problematic diseases in rice and can cause crop losses of up to 50\% [3]. Recently studies of Xoo in rice fields of Vietnam reported different races with diverse reactions because contained different resistance genes [4]. In fact, until now there is no effective pesticide against bacterial blight even though outbreaks occurring in most rice-growing countries. Many protein related to the peptidoglycan synthesis has proven to be a well-established and validated target for antibacterial research, since it is the site of action of the clinically important $\beta$-lactam and glycopeptide 
classes of antibiotics [5]. Each of the disaccharide-pentapeptide peptidoglycan structure is a specific and essential component of the bacterial cell wall [6]. Consequently, the MurE enzyme is highly specific for the relevant amino acid, as avoid incorporation of incorrect amino acids into the macromolecule it could result in deleterious morphological changes and then cellular lysis [7, 8]. The enzyme catalyzes the addition of D-glutamic acid to the cytoplasmic intermediate UDP-MurNAc-l-Ala (UMA; Fig. 1).

MurE ligase involved in the peptidoglycan (PG) biosynthetic pathway are characteristic of eubacteria and are absent in humans. Because of condensing of the correct species-specific amino acid substrate, MurE ligase is critical to forming cross-linkages in glycan strand, thus it plays a key role in maintaining PG integrity. Indeed, addition of the incorrect amino acid at the third position of the PG peptide moiety can result in morphological changes and bacterial cell lysis. Recently the MurE liagse structure of the Staphylococcus aureus with substrates was elected important residues for the formation of the amino acidbinding pocket. Up to now, several different approaches have been used to monitor enzyme activity of the bacterial enzyme, which is amenable to high-throughput screening by discovery of novel ATP-competitive inhibitors of MurE [10,11]. More specially, each of which not only showed the common catalytic mechanism for their condensing function, but also share conserved amino acid regions and structural features such as C-terminal domains response to binding UDP precursor substrates. But, in fact almost at the ATP binding site of the Mur ligases is remained a highly variable region, sequence identities ranging from 22 to $26 \%$. Almost conserved amino acid of them including with vital glutamates and histidines, are responsible for coordinating the $\mathrm{Mg}^{2+}$ ions [11-13].

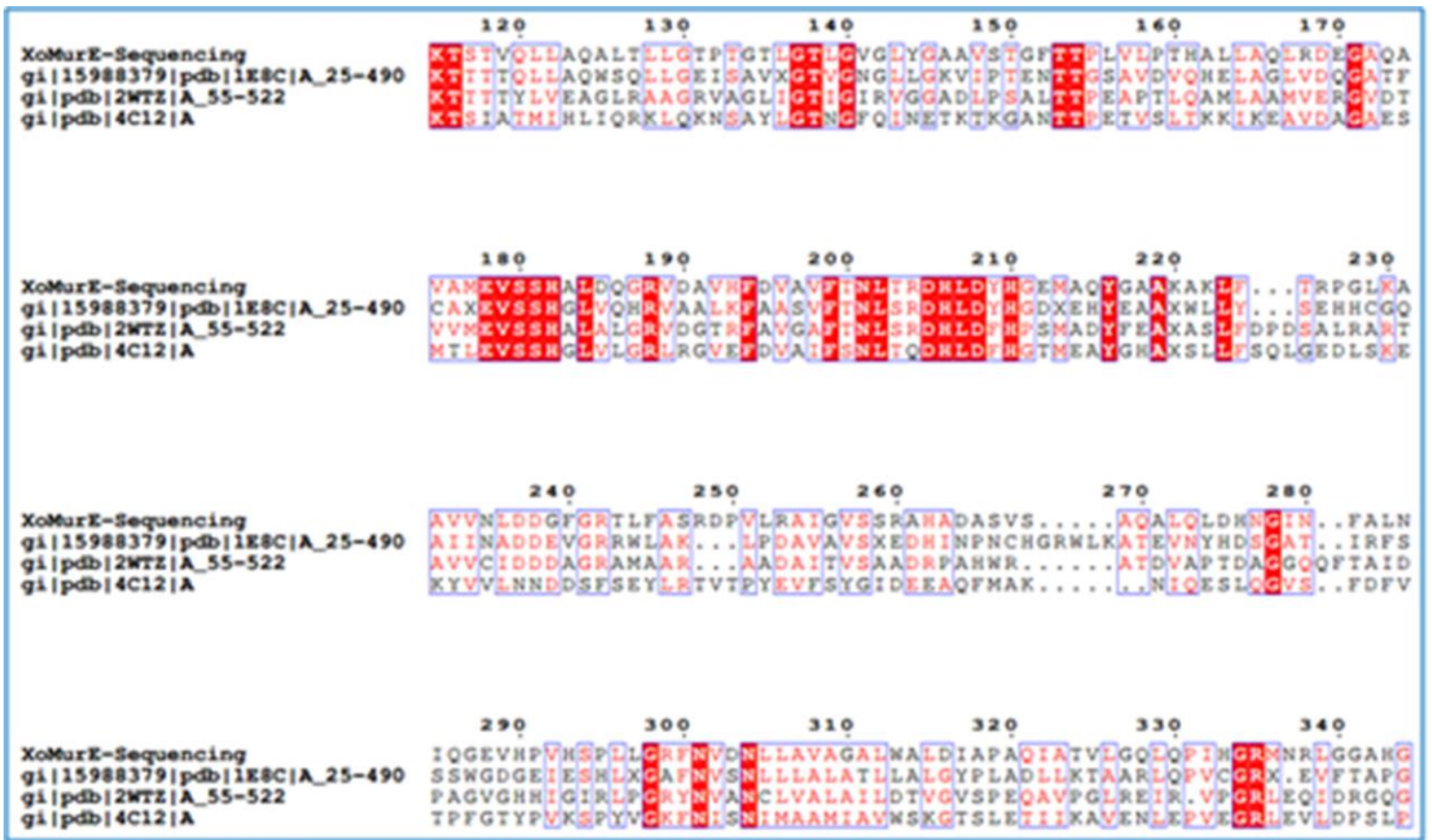

Figure 1.2 Amino acid sequences alignment for modeling: alignment of the XooMurE protein sequence (Accession No. AE013598.1) As the template sequence with that from three reference strains, E.coliMurE (PDB ID 1E8C); $M$. tuberculosisMurE (PDB ID 2WTZ); S. aureusMurE (PDB ID 4C12). (A) Amino acid sequences alignment at the ATP binding site of the four compared MurE ligases, in which reserved amino acids related to this site indexed below purple lines.

Due to the common catalytic mechanism and conserved motifs of the Mur ligases discovering a potential inhibitors against one kind of MurE may inhibit one or more of the group of enzymes. Thus it provides a potential counter mechanism averse to development of possible resistance [14]. Since the structure of XooMurE has not been determined experimentally till now, homology modeling was used to construct a three-dimensional model of the protein. A Blastp search of the XooMurE XooMurE sequence (Accession 
No. AE013598.1) Aligned sequences to that in the PDB database revealed XooMurE with chain A of MurE in E.coli (PDB ID 1E8C) as the closet homolog, with 44\% identity, and that opposed to MurE of $M$. tuberculosis and S.aureus are sequential $41 \%$ and $34 \%$, respectively (Supplementary Fig. S1)

Accordingly, the binding ability of ATP molecule with MurE ligase of Xoo is ideal to finding out novel strategized targets for the development of new classes of antibacterial compounds [15]. A fully elucidated enzymatic mechanism supposed based much more results from high-throughput screening of natural products, or structure-based virtual screening and inhibitory investigations [7]. Hence, a directed interference in wall peptidoglycan biosynthesis by inhibition to the XoMurE activity will allow the development of inhibitor against Xanthomonas oryaze. Response to this purpose, we have cloned, overexpressed, and purified MurE from Xanthomonas oryaze (XoMurE). The results revealed that XoMurE ligase was produced by the BL21(DE3) cell and harvested this enzyme following through two times purification by the Ni-NTA column. As the results in purification effectiveness over $95 \%$ purity in this study, XooMurE could utilize as an essential material in estimation studies for specificity binding ability of XooMurE with nucleotide substrates in vitro condition and consequently available for discovering attractive targets in the development strategies of novel anti-bacterial compounds. Inhibition of MurE prevents bacterial growth, which makes this enzyme an attractive and viable target in the urgent search of novel effective antimicrobial drugs.

\section{MATERIALS AND METHODS}

\subsection{Materials and strain}

A modified version pET11a used in this study, it was provided by Professor Yeh-Jin Ahn from Sangmyung University. In order to accommodation for purifying target protein, we designed a novel construction from the original pET11 by addition nucleotides coding a tag of six histidine residues followed recognition sequence of TEV protease in the plasmid. Both sites located before recognition site NdeI restriction enzyme. It is named as the pET11a-Histag-TEV. Two restriction enzymes (NdeI and BamH1) were purchased from New England BioLabs (Massachusetss, US). Kit for purifying plasmid was purchased by Invitrogen. TEV (tobacco etch virus) protease was used to cutting his-tag by Sigma-Aldrich (USA). Other chemicals were demonstrated with the high quality.

Xanthomonas oryzae py oryzae strain KACC10331 was used as original strain for isolating XooMurE gene by polymerase chain reaction (PCR) method. The Ni-NTA His-Bind resin (Ni-NTA column) from Novagen used to to purifying the recombinant protein contains His-tag.

\subsection{Cloning of the XoMurE gene (XOO-3080) and the pET11a-Histag-TEV plasmid (Novagen)}

The XooMurE gene in X. oryzae pv. oryzae encoded a total of 495 amino-acid residues. The full-length XoMurE gene was amplified via PCR using bacterial cells (Xoo KACC10331) strain) as the template. The sequences of the forward and reverse oligonucleotide primers designed from the published genome sequence (Lee et al., 2005) were as follows: 5'-GGG CATATG AGC CGT TCC ATG GCG GCT-3' and 5'-GGA TCC TCA TGG GCG CAC TCC CAA CAC-3', respectively. The bases in bold designate the NdeI and BamHI digestion sites. The amplicon was double-digested with NdeI and BamHI, ligated into the pET11a-Histag-TEV made the recombinant clone pET11a-Histag-XooMurE, and then transformed into $E$. coli BL21(DE3).

\subsection{Expression and purification of Histag-XooMurE by Ni-NTA column}

E. coli BL21(DE3) cells containing pET11a-Histag-XooMurE were grown at $37^{\circ} \mathrm{K}$ to an $\mathrm{OD}_{600}$ of 0.5 in Luria-Bertani (LB) medium containing with $50 \mu \mathrm{g} \mathrm{ml}^{-1}$ ampicillin. To finding the optimal conditions for expressing the Histag-XooMurE, two temperature conditions of $15^{\circ} \mathrm{C}$ and $37^{\circ} \mathrm{C}$ and then three IPTG concentrations were examined to assessing expression of recombinant protein. For checking the temperature, as cultured LB media reached to $\mathrm{OD}_{600}$ 0.5, the control expression of Histag-XooMurE was induced by treating the cell with supplementary of $0.5 \mathrm{mM}$ IPTG in the cultured LB medium. After that, the culture was further incubated at $15^{\circ} \mathrm{C}$ and $37^{\circ} \mathrm{C}$ for 4,6 and 16 hours. At each test periods, $1 \mathrm{ml}$ culture solution was harvest and the centrifuged at 3000rpm (Hanil Supra 30K A1000S-4 rotor) for $15 \mathrm{~min}$ at $4^{0} \mathrm{C}$. The cell pellet was re-suspended in ice-cold lysis buffer $(25 \mathrm{mM}$ Tris- $\mathrm{HCl} \mathrm{pH} \mathrm{7.5,300} \mathrm{mM} \mathrm{NaCl,} 3 \mathrm{mM}$ and B-mercaptoethanol) and then homogenized by ultrasonication on ice (Sonomasher; S\&T Science). The 
AGAINST BACTERIA XANTHOMONAS ORYZAE PV. ORYZAE

crude cell extract was centrifuged for 15 mins at 13000rpm (Hanil) at $4^{0} \mathrm{C}$ to remove cell debris. After centrifugation, the supernatant contains soluble Histag-XoMurE and debris mixed to lysis buffer applied to $10 \%$ SDS-PAGE. Secondly, for checking the IPTG concentration, as soon as cultured LB media reached to $\mathrm{OD}_{600} 0.5$, the cells induced with varying IPTG concentrations ranged to $0.1 \mathrm{~mm} ; 0.3 \mathrm{mM}$ and $0.5 \mathrm{mM}$. Then the cells were cultured continuously at $15^{\circ} \mathrm{C}$ for an additional $16 \mathrm{~h}$ after inducing expression of HistagXooMurE. Procedure of harvesting and checking the expression of this protein is similar to the above procedure.

\subsection{Purification of Histag-XooMurE by Ni-NTA His-Bind resin column (Novagen)}

All the cells the preceding time (after 16 hours induced by IPTG) were harvested by centrifugation at $3000 \mathrm{rpm}$ (Hanil Supra $30 \mathrm{~K}$ A1000S-4 rotor) for $30 \mathrm{~min}$ at $4^{\circ} \mathrm{C}$. The cell pellet was resuspended in ice-cold lysis buffer (25mM Tris- $\mathrm{HCl} \mathrm{pH} 7.5,300 \mathrm{mM} \mathrm{NaCl}, 3 \mathrm{mM}$ and $\beta$-mercaptoethanol) and then homogenized by ultrasonication on ice (Sonomasher; S\&T Science). The crude cell extract was centrifuged for 30mins at $21000 \mathrm{~g}$ (Hanil) at $4^{\circ} \mathrm{C}$ to remove cell debris. Firstly, this column was washed using the binding buffer $(25 \mathrm{mM}$ Tris- $\mathrm{HCl} \mathrm{pH} 7.5,300 \mathrm{mM} \mathrm{NaCl}, 3 \mathrm{mM}$ ß-mercaptoethanol, and $5 \mathrm{mM}$ imidazole. Secondly, the supernatant was loaded into the Ni-NTA His-Bind resin column (Ni-NTA column) and affinity purification was performed according to the manufacturer's protocol at $4^{0} \mathrm{C}$. Third, contaminant proteins were extruded out the Ni-NTA column by using the wash 1 buffer $(25 \mathrm{mM}$ Tris- $\mathrm{HCl} \mathrm{pH} 7.5,300 \mathrm{mM} \mathrm{NaCl}, 15 \mathrm{mM} \beta-$ mercaptoethanol, and $5 \mathrm{mM}$ imidazole). Fourth, this column was loaded continuously with the wash 2 buffer $(25 \mathrm{mM}$ Tris- $\mathrm{HCl} \mathrm{pH} 7.5,300 \mathrm{mM} \mathrm{NaCl}, 30 \mathrm{mM} \beta$-mercaptoethanol, and $5 \mathrm{mM}$ imidazole) to removing later contaminant proteins. Finally, Histag-XooMurE was purified through the Ni-NTA column by the elution buffer contains a higher concentration of $250 \mathrm{mM}$ imidazole.

\subsection{Digesting histag and re-purifiying XooMurE by Ni-NTA column}

The Histag-XooMurE was eluted by using elution buffer containing $250 \mathrm{mM}$ imidazole and then dialyzed

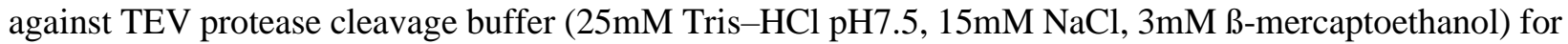
$16 \mathrm{~h}$ at $4^{0} \mathrm{C}$. After dialysis, the XooMurE protein with N-terminal His-tag was treated with a dilution series based on mass of TEV protease during $16 \mathrm{~h}$ at two temperatures of $20^{\circ} \mathrm{C}$ and $4^{\circ} \mathrm{C}$ in order to cut and then remove this tag. The XooMurE protein without the tag was again applied onto Ni-NTA His-Bind resin (Novagen) to remove any uncleaved proteins. The flow through fraction containing cleaved XooMurE was collected and applied onto a HiTrap Q anion exchange column (GE Healthcare) for further purification. The homogeneity of the purified protein was analyzed via SDS-PAGE. Finally, the purified XooMurE was concentrated using a Vivaspin 20 . The final XooMurE was appoximately $8 \mathrm{mg} / \mathrm{ml}$.

\subsection{Further purification by using anion exchange chromatography}

To investigate the purity status of XooMurE, anion exchange chromatography was employed, in which this ligase sample at $8.0 \mathrm{mg} / \mathrm{ml}$ was applied onto a (GE Healthcare) through a biologic Duaflow TM chromatography system (Bio-rad) of Sepharose Fast Flow column (Hi trap Q FF) with a flow rate of $1 \mathrm{ml} / \mathrm{min}$. XooMurE was eluted with $65 \mathrm{ml}$ linear gradient of increasing $\mathrm{NaCl}$ concentration $(0-500 \mathrm{mM})$ in combination an running buffer contains $25 \mathrm{mM}$ Tris $\mathrm{pH} 7.5$, and $3 \mathrm{mM} B$-mercapthenol. Protein elutions were monitored from its absorbance at $280 \mathrm{~nm}$.

\section{RESULTS}

\subsection{Construction of plasmid containing XooMurE gene (XOO-3830)}

The gene encoding XooMurE protein from X. oryzae pv. oryzae was amplified by PCR and then it was ligated into the expression plasmid such as pET11a-His-tag and then transformed to the competent NEB cells. The grown colonies exited in the screening LB media contain $50 \mu \mathrm{g} \mathrm{ml}^{-1}$ ampicillin has collected in order to continuously cultured overnight in LB broth. After 16 hours, the cell was centrifuged to harvesting the pET11a-His-TEV plasmid comprised XooMurE gene. The plasmid treated then by two restriction enzymes (NdeI and BamH1), the result showed that appearance of two bands corresponding to weight both of the pET11a-His-TEV and of the XooMurE gene. This result refined that the cloning procedure of XooMurE into the pET11a-His-TEV was successful. 


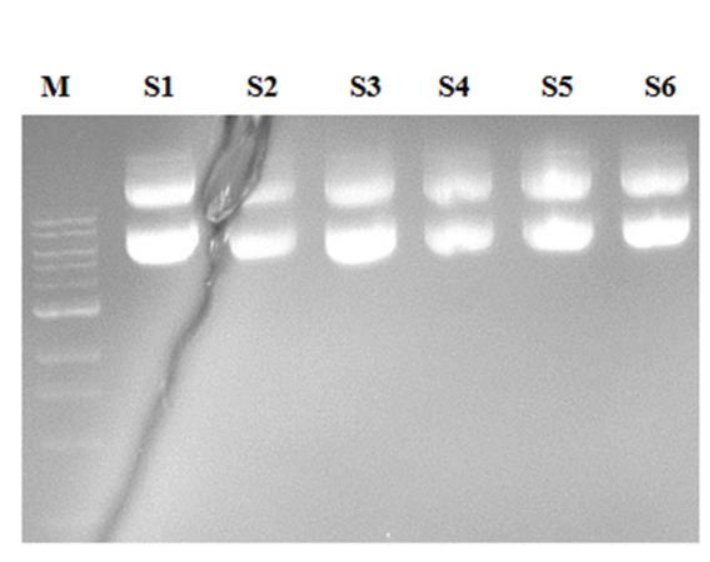

a

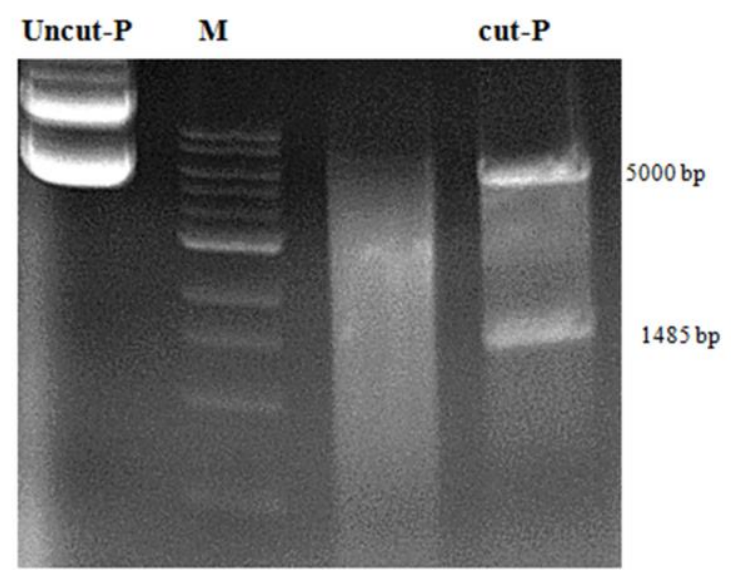

b

Figure 3.1 Purifying and checking the pET11-Histag-TEV plasmid construction contained XoMurE gene by using 2 restriction enzymes (NdeI and BamH1). a: Purifying the recombinant pET11-Histag-TEV plasmid construction from colonies grew in LB media with ampicillin concentration of 50ug/ml. Lane 1: Ladder; lane 2-6: S1 - S6 are plasmid samples. b: The comparison results of the resulting recombinant plasmid construction: lane 1: uncut recombinant plasmid; lane2: Ladder; lane 4: recombinant plasmid were cut by 2 restriction enzymes (NdeI and BamH1).

Based on the sequencing solution, all sequences of this construction revealed detailly in Fig 3.2, in which nucleotides of XooMurE gene appeared in their exact positions. Its sequent sequence also comprises one His-tag and a recognition site of TEV protease located front of XooMurE gene. The new recombinant plasmid is really valid fundamental midpoint to remove of his-tag and effective purification of any target proteins. Finally, presented peaks in the sequencing outcome refined again that the XooMurE gene inserted successfully into pET11 plasmid construction (Supplementary Fig. S2). Although having appearance of a point mutagenesis at nucleotide of 330, in which GGC codon replaced by GGG, but both coded only Glycine residue. Therefore this mutagenesis is not effect the structure of Histag-XooMurE.

\subsection{Expression and purification of Histag-XooMurE}

\subsubsection{Expression test and purification}

For the purpose of overexpression, the Histag-XooMurE was checked factors for its expression. Both factors of temperature and IPTG concentrations are initial conditions to controlling expression of recombinant protein. Therefore we examined two experiments to finding the best conditions for expression of Histag-XooMurE of Xoo. The expression tests by temperature were monitored by SDS-PAGE. The appearance of bands in a molecular mass of $58 \mathrm{kDa}$ responding to desired molecular weight exhibited exactly of harvesting Histag-XooMurE protein. This protein presented in soluble characteristic and respective bands of this protein had ascended gradually in width belongs the culture time periods. (Fig 3.3 a $\&$ b). Besides, the results also showed that Histag-XooMurE expressed in both experimental temperatures and but better in the $15^{\circ} \mathrm{C}$ after 16 hours. Next, since IPTG concentration also influences to expression of this protein. As seen in fig 3.3.c, the expression of His-tagMurE ligase protein has increase as respectively together increasing IPTG concentration. At the IPTG concentration of $0.5 \mathrm{mM}$ revealed an appreciable increased Histag-XooMurE synthesis rate opposed to less IPTG concentrations $(0.1 \mathrm{mM}$ and $0.3 \mathrm{mM})$. From these results, we gave an initial optimal condition for expression of the Histag-XooMurE is at $15^{\circ} \mathrm{C}$ until 16 hours later with induced by $0.5 \mathrm{mM}$ of IPTG concentration. All The Histag-XooMurE was purified subsequently by affinity chromatography of Ni-NTA column. 

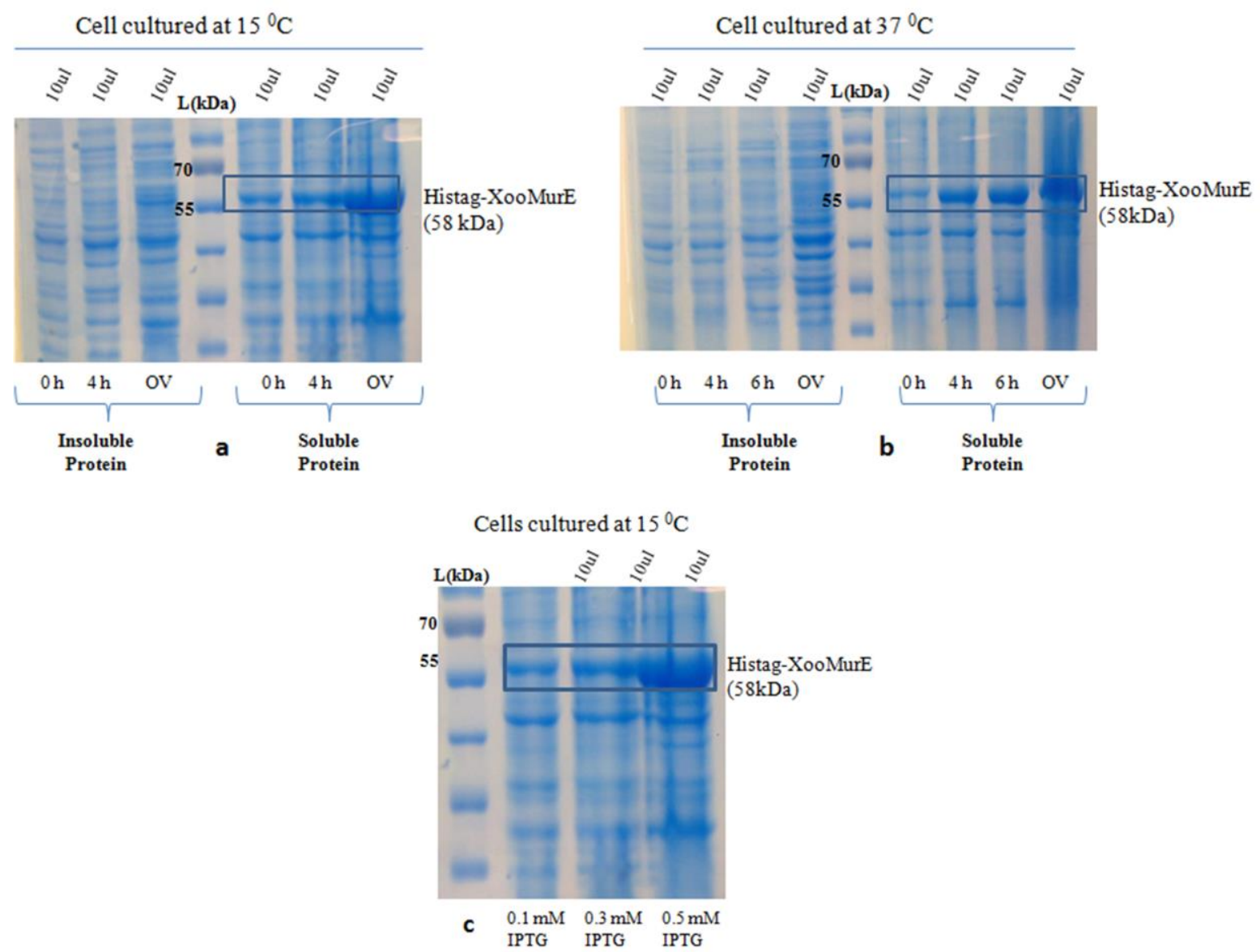

Figure 3.2 Analysis of coomasive blue-stained SDS-PAGE of expression test of the Histag-XooMurE from BL21 (DE3) contained the recombinant pET11a-Histag-XooMurE plasmid. a \& b: Surveying two temperature conditions of $15^{\circ} \mathrm{C}$ and $37^{\circ} \mathrm{C}$ for expression of the Histag-XooMurE; c: Surveying IPTG concentrations $(0.1 \mathrm{mM} ; 0.3 \mathrm{mM}$; $0.5 \mathrm{mM}$ ) for expression of the Histag-XooMurE at $15^{\circ} \mathrm{C}$ (refined optimal temperature)

3.2.2 Digesting his-tag and re-purification

Before determining biological characteristic of Histag-XooMurE for further study, this protein should be removed the involved His-tag in order to making the accurate full length of XooMurE. Therefore, the Histag at N-terminal was treated with TEV protease. Ratio of molecular weight of XooMurE and TEV protease together in two differential temperatures were used to determine a suitable condition to extracting this tag. As shown in fig3.3 a \& b, the Histag at N-terminal moved out of the purified Histag-XooMurE with differential effectives at each mixture of TEV and recombinant XooMurE. Consider the aspect of temperature condition at $20^{\circ} \mathrm{C}$, resulting much more digested the tag when increasing the pending time reached to 16 hours for each detaching reaction. In contrast, the number of separated this tag in the condition of $4^{\circ} \mathrm{C}$ is less than that in $20^{\circ} \mathrm{C}$ condition. Therefore, a qualified condition based on the ratio molecular weight of TEV and of the purified Histag-XooMurE (1:10) was chosen and reaction at $20^{\circ} \mathrm{C}$ pending in 16 hours can be provided a best satisfactory condition for both removing the His-tags and harvesting pure XooMurE. 


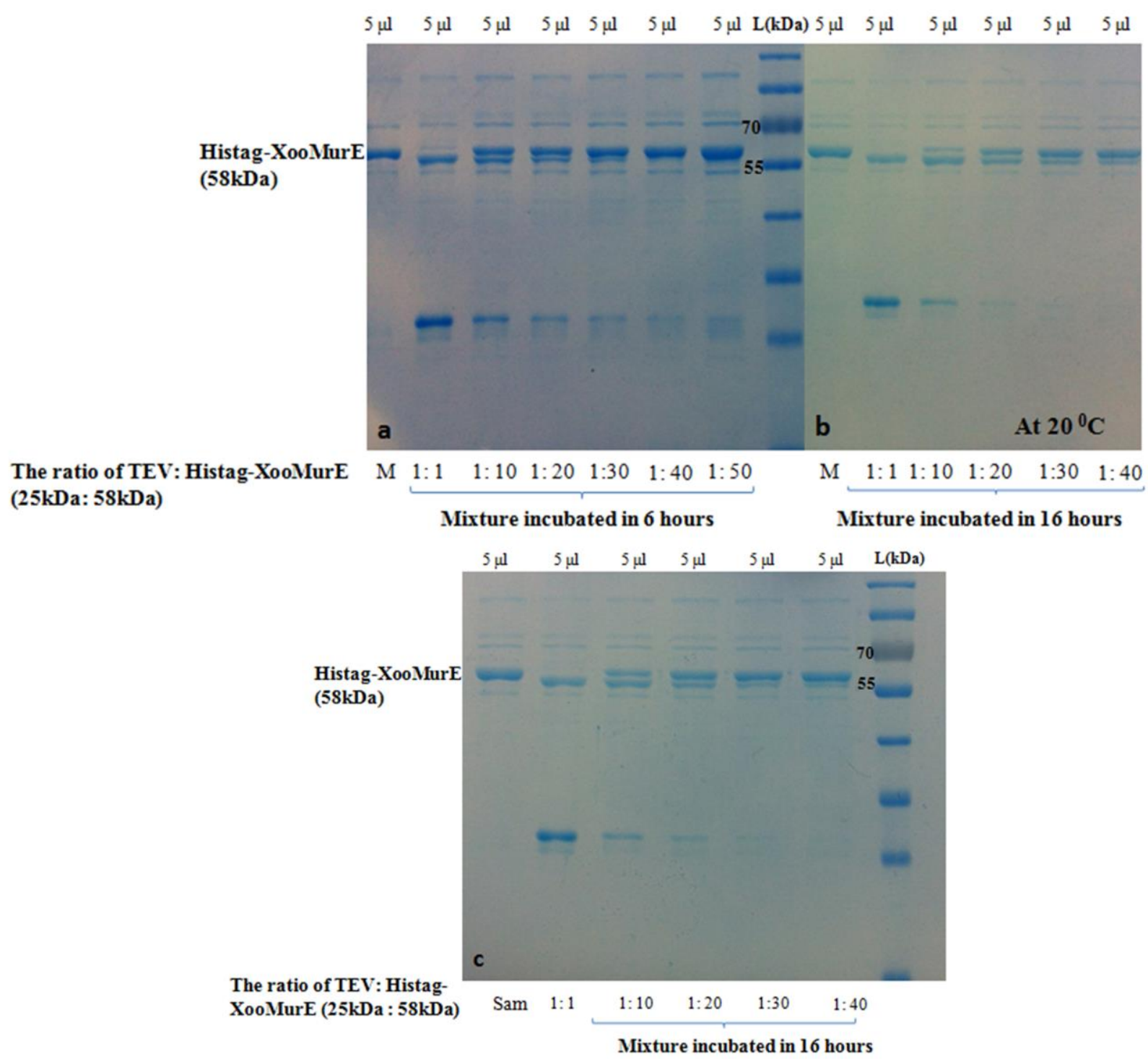

Figure 3.3 SDS-PAGE photo of cutting Histag at two surveying temperature conditions $\left(20^{0} \mathrm{C} \& 4^{0} \mathrm{C}\right)$ combined to differential ratio of TEV and Histag-XooMurE. (a): The results of the differential ratio of TEV and HistagXooMurE at $20^{\circ} \mathrm{C}$ in two time periods (6 hours and 16 hours); (b): The results of the differential ratio of TEV and Histag-XooMurE at $4^{0} \mathrm{C}$ in 16 hours

The results of detaching His-tag and purify XooMurE in larger scale (10L LB media) are shown in figure 3.4. As soon as this tag removed completely, XooMurE re-purified by the Ni-NTA in the second purification. Through extrude his-tag by TEV protease and sequential followed each stages of purification, at the same time bands incubated with TEV protease in Fig 3.5 (a) \& (b) grew down as comparing to band without TEV protease. Moreover, purity of XooMurE without His-tag also was refined by appearance only one band at the follow-through solution, which was separated with contaminant proteins such as XooMurE with His-tag and TEV protease enzyme by both retained in the Ni-NTA column. More especially after concentrating processes revealed the final bands are clearly displayed, no strange bands appear in this step, which proves that TEV protease is digested His-tag completely and produced high protein purification efficiency. 

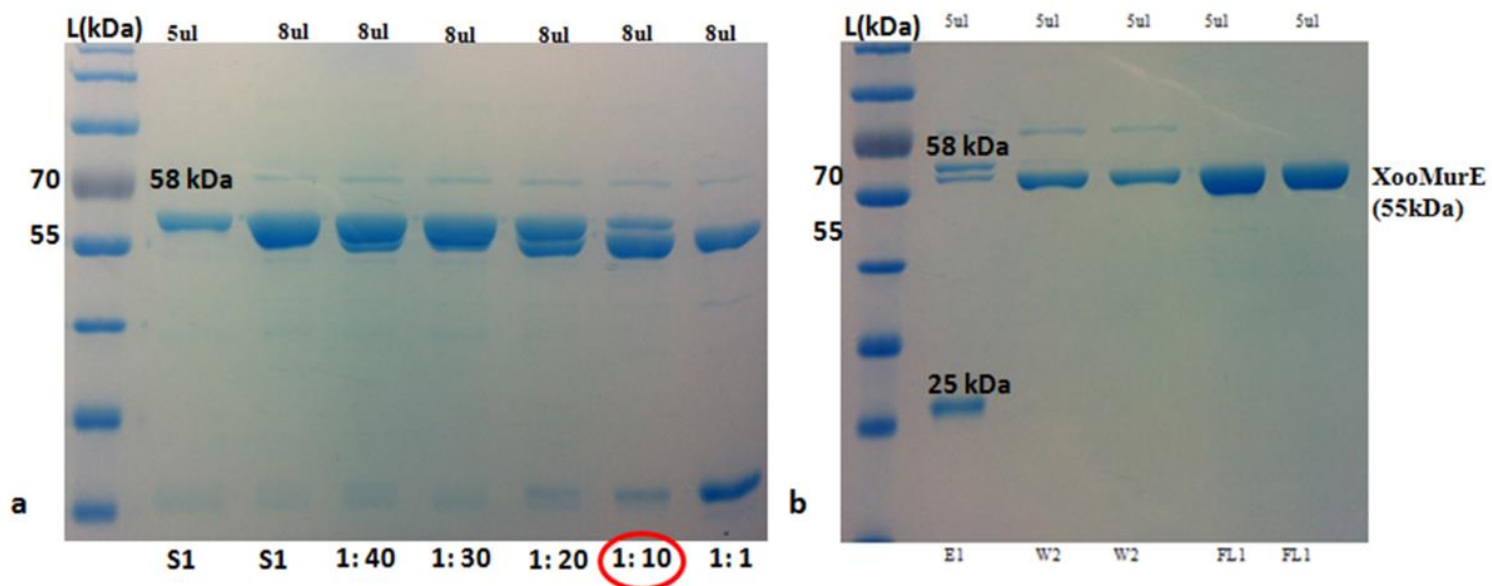

Figure 3.4 SDS-PAGE photo of the results of detaching Histag and purify XooMurE in larger scale (10000ml LB media). a: The results of the differential ratio of TEV and Histag XooMurE at $20^{\circ} \mathrm{C}$ in 16 hours); b: The results of re-purifying XooMurE without His-tag, lane 1: ladder; lane 2: Elution solution involves band of TEV protease $(25 \mathrm{kDa})$ and a little of XooMurE with Histag $(58 \mathrm{kDa})$; lane 3-4: Wash 2 solution contains XooMurE with Histag; line 5-6: Flow-through solution contains XooMurE without Histag.

\subsubsection{Further purification by using anion exchange chromatography}

Anion exchange chromatography is the power method to separate target proteins. The characteristic of the purified protein was analyzed via the peaks observed in chromatography (Fig 3.5).

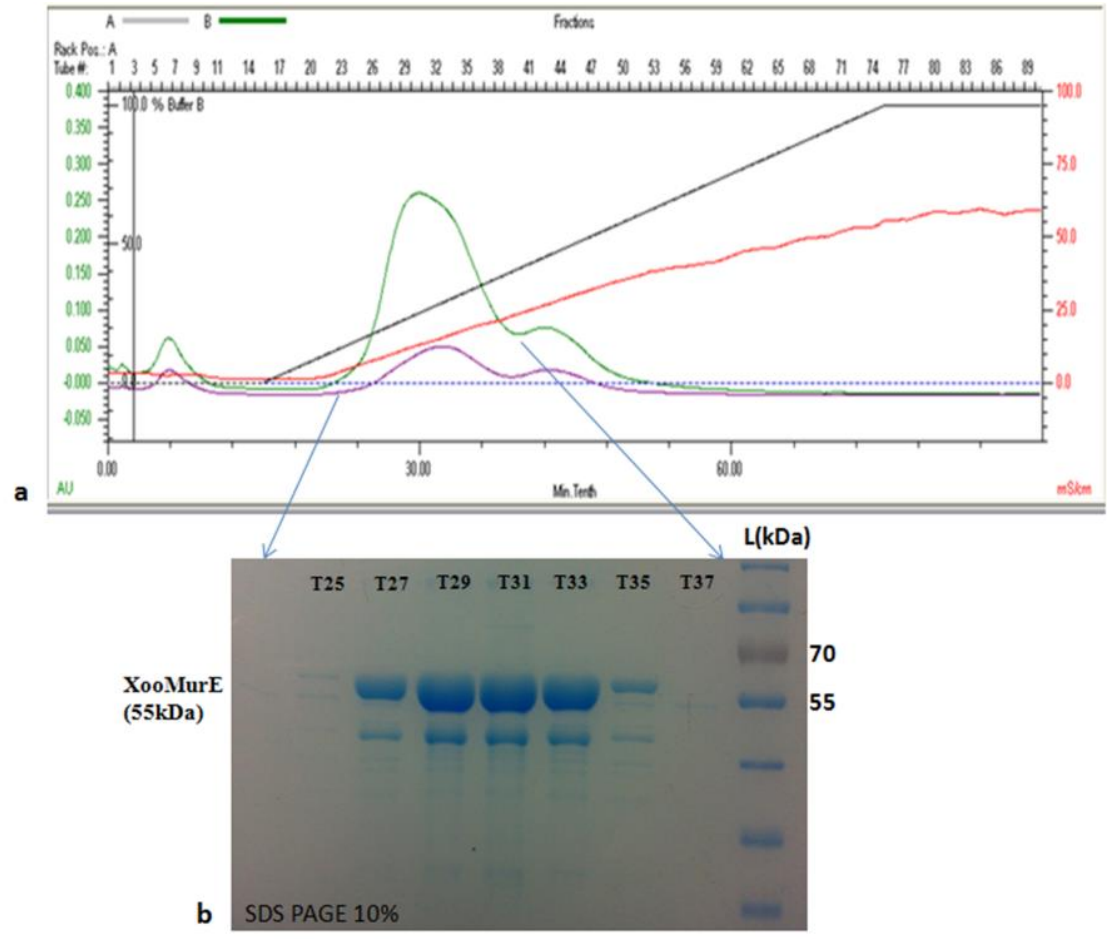

Figure 3.5 Scheme of the purification protocol. a, Elution of the XooMurE from a Sepharose Fast Flow column (Hi trap Q FF) during the last chromatography step. b, SDS-PAGE (10\%) analysis of samples taken during the purification procedure and of fractions indicated with red numbers in a. Lane 1-7, samples analysed anion exchange chromatography. Lane 2: protein ladder. Lane 4, sample after anion exchange chromatography. 
XooMurE could be detected initially at a concentration of $12.5 \mathrm{mM} \mathrm{NaCl}$ involved in the running buffer. As the results shown in the fig 3.6, according to observed peaks of twelve fractions in ranges of 25 to 37 via SDS-PAGE showed that high homogeneity of the XooMurE. Finally, to maintaining the biological nature of the target protein, best fractions (T29-T33) was collected and then concentrated to an appointed mass of $8 \mathrm{mg} / \mathrm{ml}$ for preservation. The purity of the XooMurE checked again via SDS-PGE (Fig 3.5). The final amount of XooMurE was produced about $92 \mathrm{mg}$ per 10 liter of cultured media.

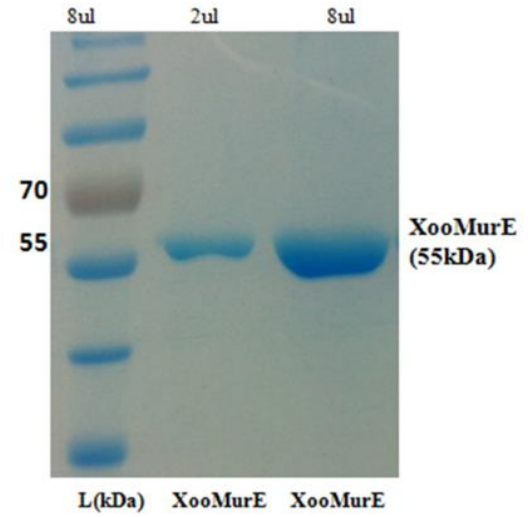

Figure 3.6 Purified XooMurE on 10\% SDS-PAGE, Lane 1: Ladder; Line 2 and 3: purified XooMurE at two different volumes $(2 \mu 1$ and $8 \mu 1)$.

\section{DISCUSSION}

Nowadays, as appearance of multiple bacterial strains resistant to currently available antibiotics may be the main reasons to distribute the spread of resistance mechanisms among emerging and re-emerging bacterial pathogens. Some enzymes involved in its cell wall peptidoglycan biosynthesis were considered as potential therapeutic targets. One of these genes, a gene coded for uridine diphosphate (UDP)-MurNAc-tripeptide ligase (MurE), catalyses the addition of meso-diaminopimelic acid (m-DAP) into peptidoglycan by coupled to the hydrolysis of ATP has more popular interest. Until now, biochemical and structural characterization of MurE from pathogen bacteria were studied much, such as MurE liagse from Escherichia coli, Pseudomonas aeruginosa, Mycobacterium tuberculosis, Chlamydia trachomatis, Staphylococcus aureus or Yersinia pestis [12, 13, 16-19]. By the way, the results of enzyme kinetics of the amide ligase MurE also determined by using the synthesized nucleotide substrate UDPMurNAc- Ala-Glu (uridine 5_-diphosphoryl $\mathrm{N}$-acetylmuramoyl-Lalanyl-D-glutamate) [13, 16, 20]. Furthermore, the MurE ligase from Yersinia pestis recently considered as a case study to identification of potential drug targets in metabolic pathway analysis [19].

Because of structure and function of the MurE enzyme play an important role in development of novel inhibitors [15]. In fact, the structure of MurE ligase of Xoo has not been determined experimentally now, and amino acid sequence of XooMurE liagse showed high homologous with these ligases involved in three pathogen bacteria such as E. coli, M. tuberculosis, S. aureus, that ranging from 34 to $40 \%$ identify. The results in sequence analysis of MurE ligase from Xoo and the other reference also refined changeable amino acids at the ATP binding site located in the central domain of each structures (Supplementary Fig. S3). Hence, based on similarity with homologous enzymes such as MurE ligase of E. coli, producing the high pure quality of XooMurE could provide a highly specific material to study of finding novel catalysis mechanism of XooMurE, and then consequently potential inhibitor in research its inhibition activity. Inhibition of the activity of XooMurE could prevent bacterial growth, which makes this enzyme an attractive and viable target in the urgent search of novel effective antimicrobial drugs.

\section{CONCLUSION}

Xanthomonas oryzae is causal agent of bacterial blight (BB) in rice. In which, uridine diphosphate (UDP)MurNAc-tripeptide ligase (MurE), catalyses the addition of meso-diaminopimelic acid (m-DAP) into 
peptidoglycan by coupled to the hydrolysis of ATP has generated renewed interest. Because of structure and function of the Mur enzymes considered for development of novel inhibitors[7]. Hence, in this study, the XooMurE of Xoo was over-expressed in the cytoplasm of Escherichia coli cells. After detaching Histag out of this protein, the purified XooMurE was further purified by an assay of anion exchange chromatography, and monitored by SDS-PAGE. The results showed this protein exhibited a molecular mass of 51, $36 \mathrm{kDa}$. The yield was $92 \mathrm{mg}$ per 10 liter of culture. Finally, the purity effectiveness of XooMurE over $95 \%$ could provide an essential material in the purpose assessment studies for specificity binding of MurE ligase with nucleotide substrates in vitro. It could consider as a basic result for discovering attractive targets in the development of new anti-bacterial compounds.

\section{APPENDIX}

Supplementary Fig. S1: The estimated homology results of XooMurE gene from NCBI (AE013589.1) and aligned sequences to that in the PDB database with chain A of MurE in E.coli (PDB ID 1E8C) as the closet homolog, with $44 \%$ identity, and that opposed to MurE of M. tuberculosis and S.aureus are sequential $41 \%$ and $34 \%$, respectively

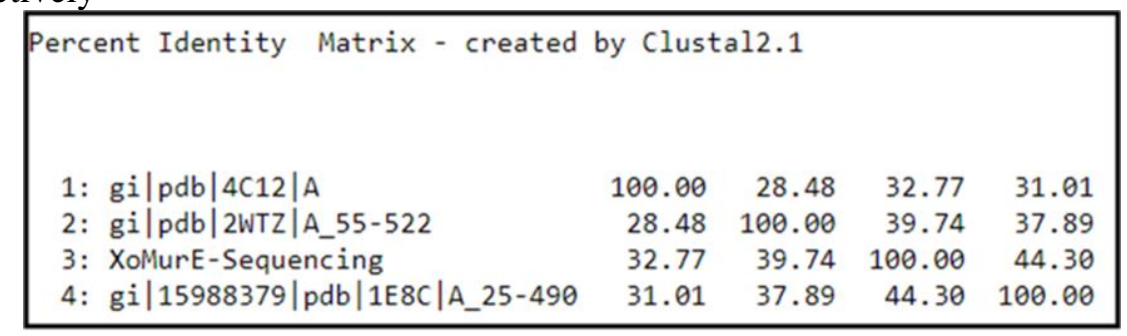

Supplementary Fig. S2: The aligned results of XooMurE gene from NCBI (AE013589.1) and XooMurE gene involved the pET11 plasmid construction

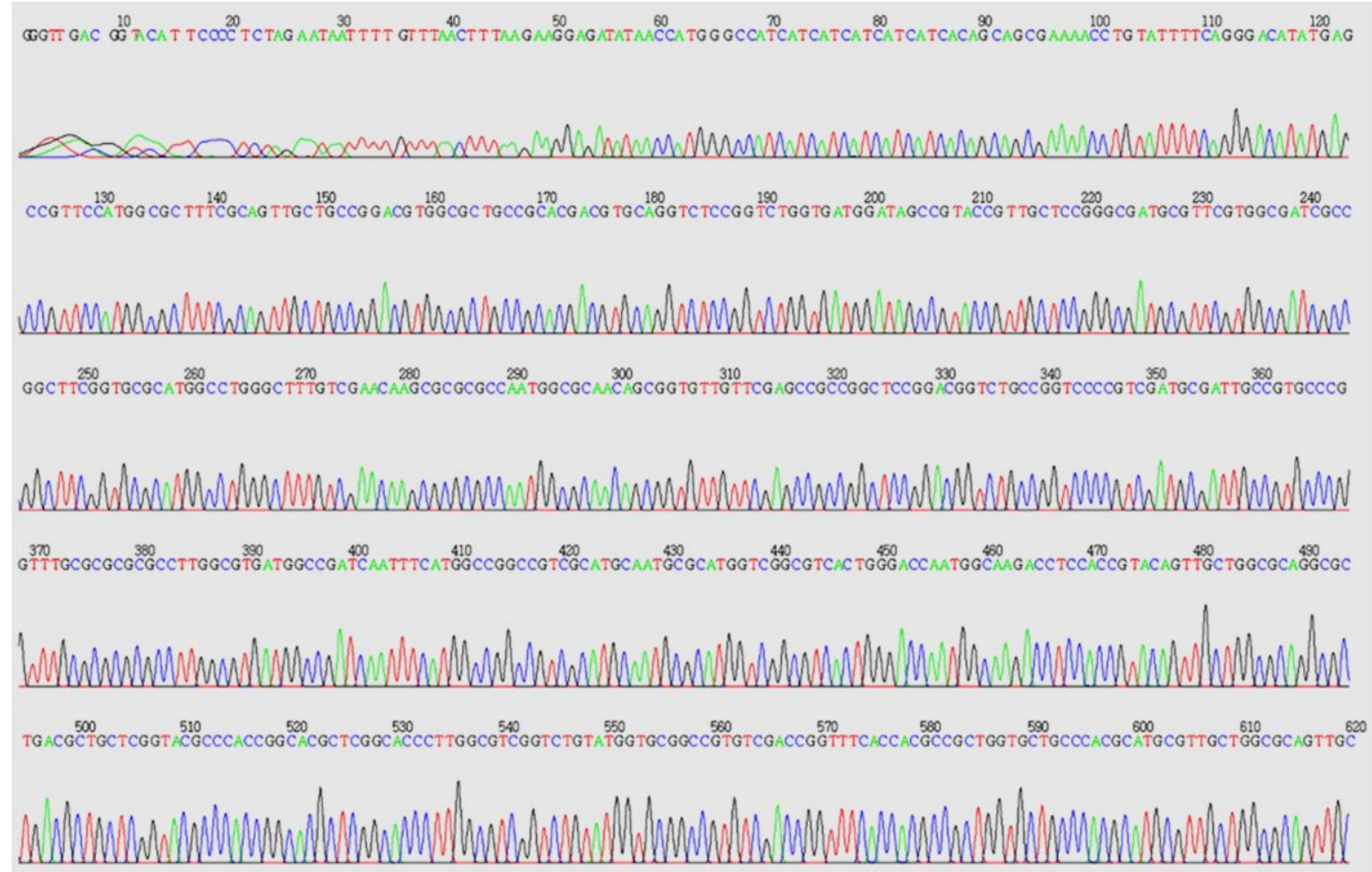

Supplementary Fig. S3: Amino acid sequences alignment for modeling: alignment of the XooMurE protein sequence (Accession No. AE013598.1) as the template sequence with that from three reference strains, E.coliMurE (PDB ID 1E8C); M. tuberculosisMurE (PDB ID 2WTZ); S. aureusMurE (PDB ID 4C12). Three functional domains in each sequence of MurE were refined by colored boxes. N-terminal domain indexed by green box; Central domain indexed blue box; C-terminal domain indexed by purple box 


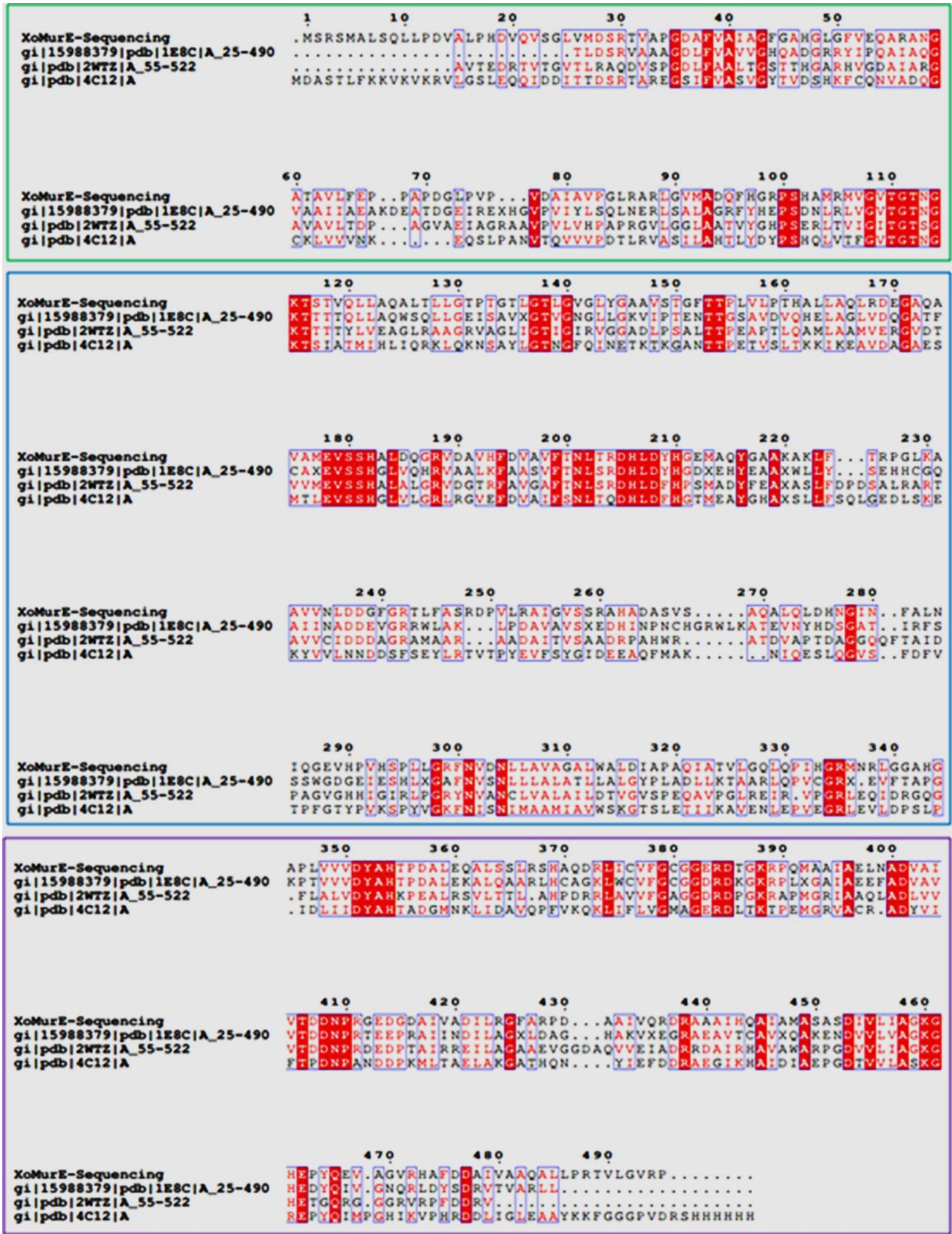




\section{REFERENCES}

[1]. FAOSTAT, Available online: http://faostat.fao.org (accessed on 1 August 2019). 2019.

[2]. Khush, G.S., What it will take to feed 5.0 billion rice consumers in 2030. Plant Mol. Biol., 2005. 59: p. 1-6.

[3]. Verdier, V.V.C., C.; Leach, J.E., Controlling rice bacterial blight in Africa: needs and prospects. J. Biotechnol., 2012. 159: p. 320-328.

[4]. Tran Quoc Tuan, L.T.H., Nguyen Dac Khoa, Population diversity of Xanthomonas oryzae pv. oryzae causing bacterial leaf blight in rice fields of Can Tho. Journal of Biotechnology, 2017. 15: p. 753-761.

[5]. DHB, T., Bacterial Peptidoglycan Biosynthesis and its Inhibition. Comprehensive Natural Products Chemistry. Oxford: Pergamon, 1999: p. 241-294.

[6]. Vollmer W, B.D., de Pedro MA, Peptidoglycan structure and architecture. FEMS Microbiol Rev, 2008. 32: p. 149-167.

[7]. Imène Kouidmi, R.C.L.a.C.P.-B., The biology of Mur ligases as an antibacterial target. Molecular Microbiology, 2014. 94: p. 242-253.

[8]. H’ ele`ne Barreteau1, A.K., Audrey Boniface1, Matej Sova, Stanislav Gobec \& Didier Blanot, Cytoplasmic steps of peptidoglycan biosynthesis. FEMS Microbiol Rev, 2008. 32: p. 168-207.

[9]. Debanu Das, M.H., Julie Feuerhelm, Carol L. Farr, Hsiu-Ju Chiu, Marc Andre’ Elsliger, Mark W. Knuth, Heath E. Klock, Mitchell D. Miller, Adam Godzik, Scott A. Lesley, Ashley M. Deacon, Dominique Mengin-Lecreulx, Ian A. Wilson, Structure and Function of the First Full-Length Murein Peptide Ligase (Mpl) Cell Wall Recycling Protein. Plos One, 2011. 6(3).

[10]. Katja Kristan, Marko Oblak and Uros Urleb, New High-Throughput Fluorimetric Assay for Discovering Inhibitors of UDP-N-Acetylmuramyl-l-Alanine:d-Glutamate (MurD) Ligase. Journal of Biomolecular Screening, 2009. 14(412-418).

[11]. Martina Hrast, K.R., Iza Ogris, Veronika Škedelj, Delphine Patin, Matej Sova, Hélène Barreteau, Stanislav Gobec, Simona Golič Grdadolnik \& Anamarija Zega, Evaluation of the published kinase inhibitor set to identify multiple inhibitors of bacterial ATP-dependent mur ligases. Journal of enzyme inhibition and medicinal chemistry, 2019. 34(1): p. 1010-1017.

[12]. Chandrakala, B., Giles Robertson, Tulika Munshi, Nicholas H.Keep, SanjibBhakta, ATP-dependent MurE ligase in Mycobacterium tuberculosis: Biochemical and structural characterisation. Tuberculosis, 2010. 90: p. 16-24.

[13]. E Gordon 1 , B.F., L Chantalat, J van Heijenoort, D Mengin-Lecreulx, O Dideberg, Crystal structure of UDP$\mathrm{N}$-acetylmuramoyl-L-alanyl-D-glutamate: meso-diaminopimelate ligase from Escherichia coli. J.Biol. Chem, 2001. 276: p. 10999-1006.

[14]. Ahmed El Zoeiby, F.S.a.R.C.L., Structure and function of the Mur enzymes: development of novel inhibitors. Molecular Microbiology, 2003. 47(1): p. 1-12.

[15]. Imène Kouidmi, R.C.L.a.P.-B., The biology of Mur ligases as an antibacterial target. Molecular Microbiology, 2014. 92(2): p. 242-253.

[16]. Catherine, A.L., Franc ois, Halim, Tom, Anne, Chris D, David I., Timothy D. H. and Roger C, Pseudomonas aeruginosa MurE amide ligase: enzyme kinetics and peptide inhibitor. Biochem. J. , 2009. 421: p. $263-272$.

[17]. Delphine Patin, Julieanne Bostock, Didier Blanot, Dominique Mengin-Lecreulx and Ian Chopra, Functional and Biochemical Analysis of the Chlamydia trachomatis Ligase MurE. Journal of Bacteriology. 2009: p. 7430-7435.

[18]. Delphine Patin, A.B., Andreja Kovač, Mireille Hervé, Sébastien Dementin, Hélène Barreteau, Dominique Mengin-Lecreulx, Didier Blanot, Purification and biochemical characterization of Mur ligases from Staphylococcus aureus. Biochimie, 2010. 92(12): p. 1793-1800.

[19]. Aditya Sharma 1, A.P., Identification of potential drug targets in Yersinia pestis using metabolic pathway analysis: MurE ligase as a case study. European Journal of Medicinal Chemistry, 2012. 57: p. 185-195.

[20]. Khadijo Osmana, Dimitrios Evangelopoulosb, Chandrakala Basavannachary, Antima Guptab, Timothy D. McHughc, Sanjib Bhaktab,Simon Gibbonsa, An antibacterial from Hypericum acmosepalum inhibits ATP-dependent MurE ligase. International Journal of Antimicrobial Agents, 2012. 39: p. 124-129.

\section{TẠO DÒNG VÀ BIỂU HIÊN MÔTT ENZYME MURE LIGASE NHƯ LÀ MỘT TÁC NHÂN TIỀM NĂNG CHỐNG VI KHUẦN XANTHOMONAS ORYZAE PV. ORYZAE}

Tóm tắt. Xanthomonas oryzae (Xoo) là tác nhân gây bệnh bạc lá vi khuẩn trên cây lúa. Rất nhiều gen hiêun hữu trong loài vi khuẩn đã được xác định trong những năm gần đây. Một trong những enzyme đó là enzyme uridine diphosphate (UDP) -MurNAc-tripeptide ligase (MurE) xúc tác việc bổ sung axit mesodiaminopimelic (m-DAP) vào lớp peptidoglycan bằng cách kết hợp với quá trình thủy phân ATP đã tạo ra 
sự chú ý nghiên cứu mới. Tuy nhiên, không có dữ liệu thực nghiệm để xác nhận giả thuyết này trong Xoo. Một cái nhìn tổng quan có ý nghĩa về vị trí liên kết phân tử ATP của các MurE ligase đã cho thấy có nhiều sự biến đổi của các trình tự axit amin, chiếm tỉ lệ khoảng từ 22 đến 26 phần trăm. Bên cạnh đó, cấu trúc tương đồng giữa hai cấu trúc của EcMurE and XooMurE sẽ là rất quan trọng cho xác định tiến hoá ra của hoạt tính MurE trên tế bào XXoo. Do đó, một loại protein tái tổ hợp gọi là XooMurE được tạo ra từ xoo đã được biểu hiện và tinh sạchsạch với hình thức có gắng đuôi His tại đầu N. Sau khi tinh sạch, đuôi His đã bị loại bỏ ra khỏi Histag-XooMurE bởi enzyme TEV protease. Hiệu quả tinh sạch XooMurE trên 95 phần trăm trong nghiên cứu này có thể tạo ra một vật liệu hiệu quả trong những nghiên cứu về cơ chế hoạt động của enzyme này, và định hướng cho tìm kiếm phức hợp mới có khả năng kháng khuẩn vi khuẩn Xanthomonas oryzae (xoo)

Từ khoá. Escherichia coli (E. coli), histidine-tag, pET11a plasmid, purity effectiveness.

Ngày nhận bài: 10/08/2020

Ngày chấp nhận đăng: 04/01/2021 